\title{
PROPERTIES OF PORTLAND CEMENT BASED MATERIALS MODIFIED BY SILICA FUME AND MIXED WITH SATURATED LIME-WATER
}

\author{
Metwally A. A. Abd Elaty \\ Faculty of Engineering, Structural Engineering department, Tanta University, Egypt \\ Email:drmet2828@yahoo.com
}

\begin{abstract}
On the road of minimizing air pollution and global warming by reducing the Portland cement content in Portland cement based mixes, this experimental study was conducted. Maximizing the percentage of Portland cement replaced by silica fume was tried using lime-water instead of water in mixing. That will help availability of $\mathrm{CH}$ crystals at early ages for pozzolanic reaction instead of waiting up to $\mathrm{C}_{3} \mathrm{~S}$ and $\mathrm{C}_{2} \mathrm{~S}$ hydration products.

The conducted Portland cement based materials included three groups; cement pastes, cement mortars and cement concrete mixes. The main parameters were; type of mixing solution (water or lime-water) as well as the percentages of Portland cement replaced by silica fume. Times of initial and final settings, compressive strength development, existence and intensity of $\mathrm{CH}$ crystals with age, pozzolanic activity as well as efficiency of the investigated matrices to delay the corrosion of embedded steel bars were the investigated properties.

Test results show that using lime-water in mixing delays both of initial and final setting times compared with traditional water due to the common ion effect principals. Moreover, combination use of lime-water and silica fume enhances the pozzolanic reaction that was reflected by the strength development at both early and later ages. The existence of $\mathrm{CH}$ crystals for higher percentages of silica fume (up to $30 \%$ ) for further reaction at later ages was observed by XRD results. Moreover, combined use of silica fume and lime-water ensures a high alkaline media around steel bars from the moment of ingredients mixing as long as later ages despite of pozzolanic reaction that was identified from results of chloride attack.
\end{abstract}

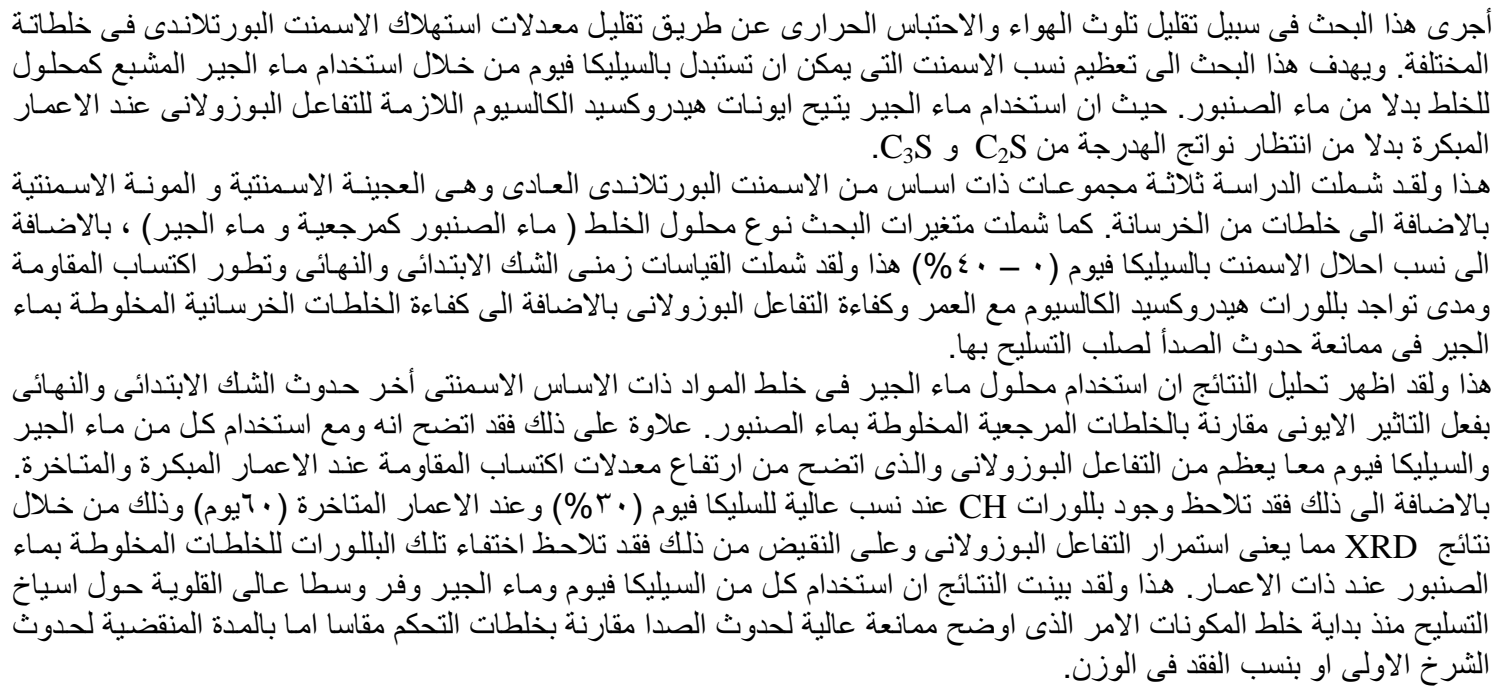

Keywords: Lime-water; Portland cement; Pozzolanic materials; Silica fume; Setting time; Hardened properties; Corrosion. 


\section{INTRODUCTION}

Several researchers have studied the use of pozzolanic materials as a mineral addition to cement based composites to obtain construction materials of enhanced engineering properties. That is due to their influence on microstructure and durability of the blended cement composites [1-3]

The sources of the mineral admixtures are the byproducts of many industries. The common types of minerals from industrial by-products are fly ash, rice husk ash, silica fume SF or condensed silica fume CSF, blast furnace slag and other slags. The uses of these minerals result in ecological, economic and energy saving considerations [4].

As reported by many authors, supplementary cementing materials such as SF have a beneficial influence on reinforced concrete durability [5]. Laboratory tests of silica-fume concretes have shown a reduction of concrete water permeability and concrete chloride diffusion coefficients [6]. Factors such as fineness, water to cementitious materials ratio, curing temperature and alkalinity of the pore solution have been thoroughly examined in an attempt to explain the reactivity of this material and relate its pozzolanic potential with the evolution of the hydration procedure [7].

A pozzolanic material requires calcium hydroxide $\mathrm{Ca}(\mathrm{OH})_{2}$ or $(\mathrm{CH})$ in order to form strength producing products (pozzolanic activity); whereas a cementations material contains quantities of $\mathrm{CaO}$ and can exhibit a self-cementitious (hydraulic) activity. Usually, the $\mathrm{CaO}$ content in these materials is not enough to react with all the quantity of the pozzolanic compounds; thus, they also exhibit pozzolanic activity (pozzolanic and cementitious materials). However, these materials are used in combination with Portland cement, which yields on its hydration, the $\mathrm{CH}$ essential for their activation [8]. Authors of Ref. [9] reported that SF exhibits higher pozzolanic activity than metakaolin whereas fly ash exhibits lower one compared to that for metakaolin. That is due to chemical and mineralogical compositions, pozzolanic activity, fineness ... etc.

Replacing some of the cement content in concrete mix by mineral admixtures is being recommended aim due to pollution problems. But replacing of cement in concrete by mineral admixtures produces an immediate dilution effect [10]. However an increase in the strength of concrete was observed at later ages. This is due to the well known chemical reaction between pozzolans and $\mathrm{CH}$ released from $\mathrm{C}_{3} \mathrm{~S}$ and $\mathrm{C}_{2} \mathrm{~S}$ hydration.

In essence, the liberated $\mathrm{CH}$ crystals are responsible for the formation of the passive layer around the reinforcement of reinforced concrete members. But 184 when highly active pozzolans materials are used in cement based mixes, they remove $\mathrm{CH}$ from the system and accelerate the ordinary Portland cement hydration.

Hydrated lime was used as an admixture in poured concrete in the beginning of the $20^{\text {th }}$ century [11]. That was due to the improved water tightness and impermeability. However, this use has largely disappeared due to increasing strength, finer grinding of Portland cement and the interaction of the chemical admixtures. From other points of view, the employment of pozzolan mixed with lime, of similar fineness to that of the OPC, will reduce the risk of concrete decalcification, even for large substitution volumes, starting by the $\mathrm{pH}$ rising of the water contained in pores, which would prevent the reinforcement passive protection [12]. Moreover, the effects of hydrated lime and SF on fly ash concrete in improving its early age strength and other properties were studied [13]. The air permeability of concrete containing lime and SF either decreased or remained almost the same when compared to the concrete without these ones. The addition of lime and SF also improved the sorptivity of concrete.

Due to the trend of using friendly environmental materials in the field of cement and concrete industries, complete utilization of cementitious and pozzolanic by-products are highly recommended $[14,15]$. However, the need for increased use of supplementary cementing materials in concrete requires more available $\mathrm{CH}$, which was tried through using lime putty addition to concrete mixes. Lime putty addition has been already proved beneficial for durability properties [16].

Authors of Ref. [17] determined compressive strength of SF mortar having proportion 1:1:6 (Cement + silica fume: lime: sand). They concluded that in Portland cement mortars, SF acts mainly at the interface paste-aggregate, where there is a higher concentration of $\mathrm{CH}$ and greater porosity than in paste. In Portland cement mortars with SF, lime is better suited in the paste and there is no evidence of concentration of SF at the interface of paste and aggregate.

Through the use of differential scanning calorimetry and thermogravimetric analysis (DSC/TG), it was demonstrated that the addition of hydrated lime increased the $\mathrm{Ca}(\mathrm{OH}) 2$ content; whereas the addition of SF decreased the $\mathrm{Ca}(\mathrm{OH}) 2$ content in the cement paste. The mercury intrusion porosimetry (MIP) data confirmed the beneficial action of hydrated lime and SF, towards decreasing the total pore volume of fly ash cement paste [13].

Since the pozzolanic reaction needs $\mathrm{CH}$ crystals to occur and keeping in mind that a period to be waited 
until the release of the $\mathrm{CH}$ crystals as a product of cement hydration and even after the release of $\mathrm{CH}$ crystals they will be consumed by pozzolanic materials through the pozzolanic reaction. All of those draw our attention to the importance of early supply cement based mixes with $\mathrm{CH}$ at early ages. This could be achieved by using saturated lime-water LW instead of water $\mathrm{W}$ in mixing. Therefore, the objective of the current study is to investigate the influence of using LW in compared with traditional mixing $\mathrm{W}$ on setting, hardening and corrosion properties of Portland cement based mixes modified by SF.

\section{Experimental Program}

An experimental program to evaluate the performance of Portland cement based materials containing SF and mixed with LW instead of $\mathrm{W}$ is designed. The efficiency of these modified mixes against chloride attack was conducted. Tables 1-3 present the schedule of the experimental program.

\subsection{Materials}

Cement: Ordinary Portland cement with Grade 42.5 MPa was used in this investigation. The used cement is conformed to the Egyptian Standard Specifications (ES) requirements (4756-1/2005).

Hydrated lime: Hydrated lime meets the specifications of ASTM Designation C 207 Standard Specification type $\mathrm{N}$ was used as a saturated soluble solution (lime-water LW) instead of tap water $\mathrm{W}$ in the proposed mixes. Partial saturated solutions were tried as mixing solutions. The partial saturation percentages were achieved through preparing solutions of LW and traditional $\mathrm{W}$ as $0 \%, 25 \%, 50 \%$ and $100 \% \mathrm{~W}$ to $\mathrm{LW}$ solution ratio by volume. LW with $\mathrm{pH}$ value of 11 was used for mortar and concrete mixes. On the other hand, saturated lime solution as a mix with $\mathrm{W}$ with different replacement percentages as $0 \%, 25 \%, 50 \%, 100 \%$ by volume of $\mathrm{W}$ were used for cement paste mixes. The prepared mixtures had $\mathrm{pH}$ values as $8,9,10$ and 11 , respectively. The corresponding measured total dissolved salts TDS values were 1000, 1000, 1100 and $1900 \mathrm{ppm}$ for the mixtures in the same order, respectively. Details of these parameters are shown in Table 1.

Aggregates: Medium well-graded sand of fineness modulus 2.27 was used. Natural well-graded gravel of $20 \mathrm{~mm}$ maximum nominal size was used; it included a combination of round and angular particles. The fine and coarse aggregates conformed to the ES requirements (1109-2002). The grading curves for the used aggregates are given in Fig. 1.
Silica fume: SF of mineral admixtures was used as replacement of cement by mass. It had 150,000 $\mathrm{cm}^{2} / \mathrm{gm}$ specific surface areas as given by the manufacturer.

\subsection{Specimen fabrication and component tests}

In general, LW is made using hydrated lime by the addition of $\mathrm{W}$ to make a saturated solution. In terms of solids (lime) content, this works out to be a mixture that is approximately $15 \%$ to $20 \%$ lime and $80 \%$ to $85 \%$ water after this procedure the soluble was left for enough time to deposit, and then the clear water of saturated lime was used.

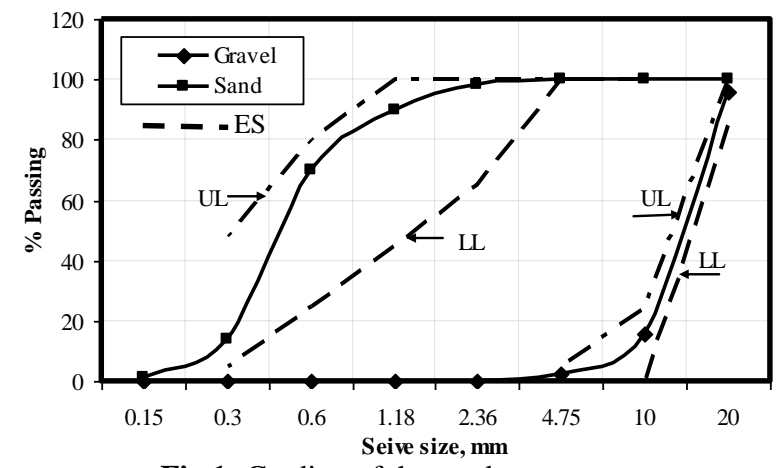

Fig.1: Grading of the used aggregates

\subsubsection{Cement paste mixes}

Twelve cement paste mixes were designed to study the effect of LW on cement hydration and the interaction with the SF. Cement pastes of standard consistency were prepared according to ASTM C 187 - 98 [18] by using Vicat apparatus. SF with $0 \%$, $10 \%, 20 \%, 30 \%$ and $40 \%$ replacement by cement mass were investigated by using ordinary $\mathrm{W}$ and $\mathrm{LW}$, Table 1 presents the cement pastes under investigation and the results of Vicat test. The specimens in their moulds (Vicat moulds) were covered with a plastic sheet and kept in the casting room at $20( \pm 1){ }^{\circ} \mathrm{C}$ for $24 \mathrm{hr}$. These were then demoulded and covered with a plastic sheet, where they remained until required age for XRD testing. XRD patterns of the hydrated samples were recorded at 3, 7, 28 and 60 days using a GNR APD 2000 PRO model $\mathrm{X}$-ray diffractometer ( $\mathrm{CuKa} \alpha$ radiation, 40 $\mathrm{kV}, 30 \mathrm{~mA}$ ) in a scanning range of $5-65^{\circ}$ in $2 \theta$ scale. The testing rate that was applied was $0.02 \%$ for all test specimens. 
Table 1: Schedule of program for cement paste mixes and results of Vicat test

\begin{tabular}{|c|c|c|c|c|c|c|}
\hline \multirow{2}{*}{$\begin{array}{c}\text { Code of } \\
\text { cement } \\
\text { paste mix }\end{array}$} & \multirow{2}{*}{$\begin{array}{c}\text { Type of } \\
\text { mix } \\
\text { solution }\end{array}$} & \multirow{2}{*}{$\begin{array}{c}\text { SF } \\
\dot{\%} \\
\end{array}$} & \multirow{2}{*}{$\begin{array}{c}\mathrm{W} /(\mathrm{C}+ \\
\mathrm{SF})\end{array}$} & \multirow{2}{*}{$\begin{array}{l}\text { TDS, } \\
\text { PPm }\end{array}$} & \multicolumn{2}{|c|}{ Setting time, $\min$} \\
\hline & & & & & Initial & Final \\
\hline $\begin{array}{c}\text { P0W } \\
\text { (Control) }\end{array}$ & $\mathrm{W}$ & - & 0.3 & 1000 & 105 & 215 \\
\hline P025LW & $\begin{array}{c}(25+75) \\
(\mathrm{LW}+\mathrm{W})\end{array}$ & - & 0.3 & 1000 & 105 & 220 \\
\hline P050LW & $\begin{array}{c}(50+50) \\
(\mathrm{LW}+\mathrm{W})\end{array}$ & - & 0.3 & 1100 & 115 & 235 \\
\hline P10W & \multirow{4}{*}{$\mathrm{W}$} & 10 & 0.33 & 1000 & 160 & 220 \\
\hline P20W & & 20 & 0.38 & 1000 & 165 & 265 \\
\hline P30W & & 30 & 0.45 & 1000 & 150 & 275 \\
\hline P40W & & 40 & 0.54 & 1000 & 135 & 300 \\
\hline $\begin{array}{c}\text { P0LW } \\
\text { (Control) }\end{array}$ & \multirow{5}{*}{ LW } & 0 & 0.3 & 1900 & 135 & 245 \\
\hline P10LW & & 10 & 0.33 & 1900 & 170 & 250 \\
\hline P20LW & & 20 & 0.38 & 1900 & 195 & 288 \\
\hline P30LW & & 30 & 0.45 & 1900 & 165 & 295 \\
\hline P40LW & & 40 & 0.54 & 1900 & 150 & 330 \\
\hline
\end{tabular}

\subsubsection{Cement mortar mixes}

Eight mortar mixes were cast and tested. Mortar cubes measuring $70 \times 70 \times 70 \mathrm{~mm}$ were made to record the compressive strength of mortar up to 60 days. SF with $0 \%, 10 \%, 20 \%$ and $30 \%$ replacement by cement mass were conducted (refer to Table 2). A universal testing machine of $300 \mathrm{kN}$ total capacity was used. An electrical driven mechanical mixer of 3 $\mathrm{L}$ total capacity was used. The mixing procedure includes pre-mixing the SF (when present) with the cement, adding the mixing $\mathrm{W}$ or $\mathrm{LW}$ when applied until wet, and then adding the aggregate in preparation for final blending. Final mixing proceeded for $3 \mathrm{~min}$, was halted for one minute, while the mixing bowl walls were scraped down, and resumed for a second period of $2 \mathrm{~min}$. The mixes were cast in steel cubes molds and were vibrated for $10 \mathrm{sec}$ on a vibrating table to aid in consolidation. All cubes were demolded after 24 hrs with some being set aside to comprise the 1-day samples. The remainder were placed in water and cured until the age of testing.

Table 2: Schedule of program for mortar mixes

\begin{tabular}{|c|c|c|c|c|}
\hline $\begin{array}{c}\text { Code of } \\
\text { mortar } \\
\text { mix }\end{array}$ & $\begin{array}{l}\text { Type of } \\
\text { mix } \\
\text { solution }\end{array}$ & SF, \% & $\begin{array}{c}\text { Mix } \\
\text { Proportion } \\
\text { by weight }\end{array}$ & Tests \\
\hline $\begin{array}{l}\text { M0W } \\
\text { (control) }\end{array}$ & \multirow{4}{*}{ ( } & 0 & \multirow{4}{*}{$\begin{array}{c}\text { 1: } 2.5: 0.5 \\
\text { C+SF: S:W }\end{array}$} & \multirow{8}{*}{$\begin{array}{c}\text {-Compressive } \\
\text { strength at } \\
(3,7,28 \text { and } \\
60) \text { days }\end{array}$} \\
\hline M10W & & 10 & & \\
\hline M20W & & 20 & & \\
\hline M30W & & 30 & & \\
\hline $\begin{array}{l}\text { M0LW } \\
\text { (control) }\end{array}$ & \multirow{4}{*}{ LW } & 0 & \multirow{4}{*}{$\begin{array}{c}\text { 1: } 2.5: 0.5 \\
\text { C+SF: S: LW }\end{array}$} & \\
\hline M10LW & & 10 & & \\
\hline M20LW & & 20 & & \\
\hline M30LW & & 30 & & \\
\hline
\end{tabular}

\subsubsection{Concrete mixes}

Eight concrete mixes were cast and tested. SF with $0 \%, 10 \%, 20 \%$ and $30 \%$ replacement by cement mass were investigated. Concrete cubes measuring $150 \times 150 \times 150 \mathrm{~mm}$ were prepared to follow the compressive strength gain of concrete up to 60 days (refer to Table 3), a hydraulic testing machine of $1550 \mathrm{kN}$ total capacity was used. The concrete mixes were mixed as the same sequences established for mortar mixes using mechanical mixer of $100 \mathrm{~L}$ capacity. After complete mixing, slump test according to the procedure described in Egyptian Code ECP 203:2009 and ASTM C143 standards, was conducted to keep plastic consistency for all mixes. All specimens were cured by immerging in a water tank at $20{ }^{\circ} \mathrm{C}$ until the day of testing and for a total curing period of 28 days. After 28 days, the specimens were left in laboratory conditions. Moreover, the influence of these modified concrete mixes on steel corrosion resistance was investigated using concrete cubes specimens of $150 \mathrm{~mm}$ side dimension. The specimens were prepared and steel bar of $10 \mathrm{~mm}$ in diameter were placed in the center of the concrete cube to $100 \mathrm{~mm}$ depth. The specimens were exposed to $5 \% \mathrm{NaCl}$ solutions at a depth of 50 $\mathrm{mm}$ in fiberglass container after 28 days from casting and curing. An accelerated test for corrosion was applied by using power supply at constant current and switch to suitable voltage. Stainless steel bar with $10 \mathrm{~mm}$ diameter was used as a cathode and the steel bar act as an anode up to the cutting of the electrical cell due to the cutting the steel bars and /or over all 120 days. 
Figure 2 shows the accelerated corrosion cell arrangement. After then the specimens were taken out from the container and the steel reinforcement was extracted from the specimens and then cleaned carefully to remove the rust from the steel bars. Then the steel reinforcement bars were weighted and the percents of weight loss were calculated.

Table 3: Schedule of program for concrete mixes

\begin{tabular}{|c|c|c|c|c|c|}
\hline \multirow{2}{*}{$\begin{array}{c}\text { Code of } \\
\text { concrete mix }\end{array}$} & \multirow{2}{*}{$\begin{array}{l}\text { Type of mix } \\
\text { solution } \\
\end{array}$} & \multirow{2}{*}{$\mathrm{SF}, \%$} & \multirow{2}{*}{$\begin{array}{c}\text { Mix proportion by } \\
\text { mass }\end{array}$} & \multicolumn{2}{|c|}{ Tests } \\
\hline & & & & Fresh & Hardened \\
\hline COW (control) & \multirow{4}{*}{ W } & 0 & $\begin{array}{c}\text { 400:0:675:1015:200 } \\
\text { C:SF:S:G:W }\end{array}$ & \multirow{8}{*}{$\begin{array}{c}\text { - Slump } \\
- \\
\text { Setting } \\
\text { times }\end{array}$} & \multirow{8}{*}{$\begin{array}{c}\text {-Compressive } \\
\text { strength at ( } 3 \text {, } \\
7,28 \text { and } 60) \\
\text { days } \\
\text { - Exposure to } \\
\mathrm{NaCl} \text { at } 28 \\
\text { days }\end{array}$} \\
\hline C10W & & 10 & $\begin{array}{c}\text { 360:40:675:1015:200 } \\
\text { C:SF:S:G:W }\end{array}$ & & \\
\hline C20W & & 20 & $\begin{array}{c}\text { 320:80:675:1015:237 } \\
\text { C:SF:S:G:W }\end{array}$ & & \\
\hline C30W & & 30 & $\begin{array}{c}\text { 280:120:675:1015:250 } \\
\text { C:SF:S:G:W }\end{array}$ & & \\
\hline COLW (control) & \multirow{4}{*}{ LW } & 0 & $\begin{array}{c}\text { 400:0:675:1015:200 } \\
\text { C:SF:S:G: Lw }\end{array}$ & & \\
\hline C10LW & & 10 & $\begin{array}{c}\text { 360:40:675:1015:200 } \\
\text { C:SF:S:G: Lw }\end{array}$ & & \\
\hline C20LW & & 20 & $\begin{array}{c}320: 80: 675: 1015: 237 \\
\text { C:SF:S:G: Lw }\end{array}$ & & \\
\hline C30LW & & 30 & $\begin{array}{l}\text { 280:120:675:1015:250 } \\
\text { C:SF:S:G: Lw }\end{array}$ & & \\
\hline
\end{tabular}

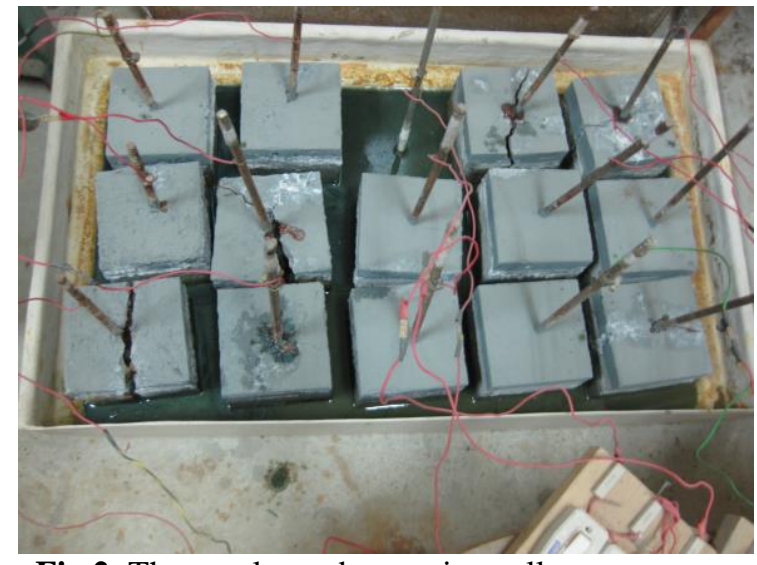

Fig.2: The accelerated corrosion cell arrangement

\section{Results and discussion}

Replacing part of cement in Portland cement concrete mixes is a target in the road of minimizing air pollution and global warming. The following Sections present the properties of Portland cement based materials mixed with either W or LW solution. Setting properties, hydration process as well as corrosion rate of embedded steel bars are the main properties evaluated in this study.

\subsection{Initial and final setting times}

3.1.1 Cement paste mixes

To investigate using of LW solution as a mixing solution, a preliminary study aimed at evaluating the degree of saturation on setting properties was conducted. The results of this study are given in Table 1. The tried degrees of saturations were $0 \%$, $25 \%, 50 \%$ and $100 \%$. The recorded initial times of setting were 105, 105, 115 and $135 \mathrm{~min}$ for the conducted mixes, respectively. Whereas, the final setting times for the same mixes were 215, 220, 235 and $245 \mathrm{~min}$, respectively. These results concluded that the best retardation was achieved with using LW at $100 \%$ degree of saturation.

The results of both initial and final setting times are presented in Fig. 3. Two series were conducted; first one was conducted using $\mathrm{W}$ as a mixing solution whereas, second one was conducted using LW as a mixing solution. For both series, SF was used as a partial replacement of cement by weight. The conducted replacement ratios were $0 \%, 10 \%$, $20 \% 30 \%$ and $40 \%$.

For mixes made up of $\mathrm{W}$ and containing SF, it can be noticed from Fig. 3 that with increasing SF content, a delay in initial setting times were observed compared to the control mix P0W. The initial setting time values are 105, 160, 165, 150 and 135 min for mixes P0W, P10W, P20W, P30W and $\mathrm{P} 40 \mathrm{~W}$, respectively. The maximum retardation of initial setting time was recorded for mix P20W with $57.14 \%$ over the control mix P0W. Moreover, the final setting time values were $215,220,265$, 275 and 300 min for mixes P0W, P10W, P20W, $\mathrm{P} 30 \mathrm{~W}$ and $\mathrm{P} 40 \mathrm{~W}$, respectively. The maximum increase in the retardation was recorded at $40 \%$ replacement as $39.5 \%$ over the control mix P0W. 
The noticed retardation in both initial and final setting times for mixes containing SF and mixed with W agree well with many previous studies [19, 20].

On the other hand and with using LW as a solution in mixing, a shift in both initial and final setting times indicating retardation in both times was noticed compared with using W, as given in Fig.3. That retardation could be explained as the hydration of $\mathrm{C}_{3} \mathrm{~A}$ is retarded by $\mathrm{CH}$ ions, which react with $\mathrm{C}_{3} \mathrm{~A}$ and water to form $\mathrm{C}_{2} \mathrm{AH} 8$ and $\mathrm{C}_{4} \mathrm{AH}_{19}$ that form a protective layer or coating on the surface of un-hydrated grains of $\mathrm{C}_{3} \mathrm{~A}$. Upon conversions of these initially formed hydrates to cubic $\mathrm{C}_{3} \mathrm{AH}_{6}$, the barrier is disrupted and the hydration proceeds again with a fairly high speed [21].

The values of initial setting times for cement pastes made up of LW and SF were recorded as 135, 170, 195, 165 and $150 \mathrm{~min}$ for mixes P0WL, P10LW, P20LW, P30LW and P40LW, respectively. Whereas, the final setting times were recorded as 245, 250, 288, 295 and $330 \mathrm{~min}$ for the same mixes, respectively. The maximum delay in initial setting time was recorded for mix $\mathrm{P} 20 \mathrm{LW}$ as $44.4 \%$ over the control mix P0LW whereas, the beigest delay in final setting time was recorded for mix P40LW as $34.7 \%$ over the control mix P0LW. These delayed values are $85.7 \%$ and $53.5 \%$ over that for control mix P0W.

Using both of SF and LW in a cement paste mix tends to delay both of initial and final setting times. The retardation part due to SF agree well with results of reference [22], which could be related to the higher specific surface area for SF that requires an increase of water demand to achieve the standard consistency.

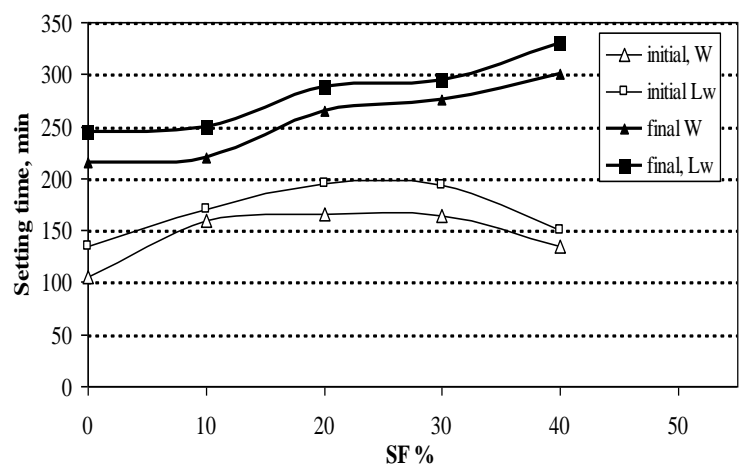

Fig. 3: Initial and final setting times for cement pastes

\subsubsection{Concrete mixes}

The results of the initial and final setting times for different concrete mixes are presented in Fig.4.

Mixes mixed using LW seem to be delayed in initial setting times. Moreover, the delay exceeds with higher SF content, the values of initial setting times were recorded as 200, 240, 270 and $327 \mathrm{~min}$ for mixes C0W, C10W, C20W and C30W, respectively. Whereas, the corresponding values for mixes C0LW, C10LW, C20LW and C30LW were 254, 291, 333 and $366 \mathrm{~min}$, respectively. The maximum delayed values were recorded at $30 \% \mathrm{SF}$ for both mixes made up of $\mathrm{W}$ and $\mathrm{LW}$. The curve representing initial setting times for mixes made up of LW seem to be parallel to that for mixes prepared with water. This shift could be considered as the influence of using LW in causing the retardation. The maximum delay periods were noticed at $30 \% \mathrm{SF}$ as $63.5 \%$ for mix C30W over the control mix $\mathrm{COW}$. Whereas, the maximum delay in initial setting time was recorded at $30 \%$ SF mixed with LW was $44.1 \%$ over mix COLW.

The difference in retardation period between mix C30LW and C0W gives the combined effect of both of SF and LW in the retardation of the initial setting time that achieves $83 \%$ over that of the control mix COW.

The trend previously noticed with initial setting times was noticed for final setting times as well. Moreover, the maximum delay in final setting time for mixes containing SF was noticed at $30 \% \mathrm{SF}$ and mixed with $\mathrm{W}$ which approaches $57 \%$ over the control mix COW. The highest delay of final setting times for mixes mixed with LW was noticed at $30 \%$ SF that approaches $43 \%$ over the corresponding control mix COLW. The combination influence of both SF and LW gives the highest value for delay in final setting times that is the difference between final setting times for C30LW and C0W. The delay of final setting time approaches the maximum value at $\mathrm{C} 0 \mathrm{LW}$ compared to $\mathrm{C} 0 \mathrm{~W}$. The recorded delay was $86 \%$ over control mix C0W.

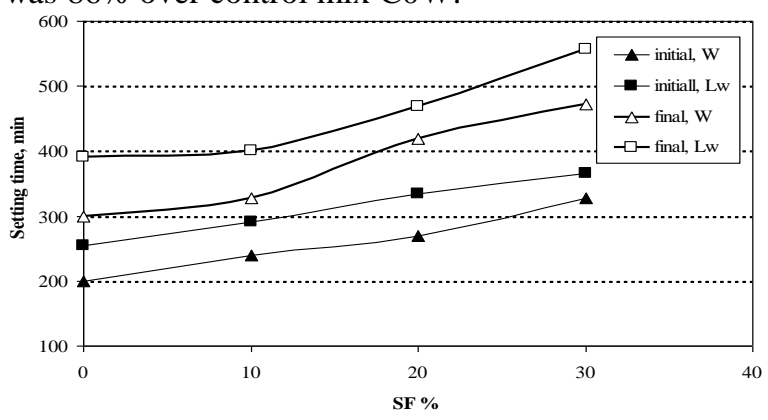

Fig. 4: Initial and final setting times for concrete mixes 


\subsection{Compressive strength development} 3.2.1 Strength development for mortar mixes Two groups of Portland cement mortar mixes were conducted. First group was mixed with $\mathrm{W}$ and contained different percentages of SF as partial replacement of cement weight. The compressive strength was investigated at $3,7,28$ and 60 days. The results are presented in Table 4 and Fig. 5. It could be noticed that the compressive strength for mortar mixes increases with the increase of SF replacement with cement by weight up to a certain SF content beyond which the strength was decreased. The maximum enhancement in compressive strength was achieved at $20 \% \mathrm{SF}$ for mix M20W as $15 \%$ over the control mix M0W at 60 days age. Whereas, for second group that was mixed with LW, at early ages, the compressive strength values seem to be higher compared to those for corresponding mortar mixes made up of $\mathrm{W}$ at similar ages. Moreover, and with increasing the SF content, the measured compressive strength was increased up to the maximum investigated SF content $30 \%$, the same trend was noticed at all the investigated ages 3, 7, 28 and 60 days. The maximum enhancement was recorded at $30 \% \mathrm{SF}$ for mix M30LW as 52\% over the control mix M0W as shown in Fig. 5. In contrary and for the mix without SF MOLW a reduction of the compressive strength was noticed at all ages.

Table 4: Test results of mortar mixes compressive strength at different ages

\begin{tabular}{|c|c|c|c|c|c|c|}
\hline \multirow{2}{*}{ Mix Code } & \multirow{2}{*}{$\begin{array}{l}\text { Type of mix } \\
\text { solution }\end{array}$} & \multirow{2}{*}{$\begin{array}{c}\mathrm{SF}, \\
\%\end{array}$} & \multicolumn{4}{|c|}{ Compressive strength, $\mathrm{MPa}$} \\
\hline & & & 3 & 7 & 28 & 60 \\
\hline $\begin{array}{c}\text { M0W } \\
\text { (control) }\end{array}$ & \multirow{4}{*}{ W } & 0 & 4.1 & 5.8 & 7.7 & 8.9 \\
\hline M10W & & 10 & 3.6 & 5.0 & 8.8 & 9.9 \\
\hline M20W & & 20 & 3.4 & 5.0 & 8.2 & 10.2 \\
\hline M30W & & 30 & 3.3 & 5.2 & 8.1 & 10.1 \\
\hline $\begin{array}{l}\text { M0LW } \\
\text { (control) }\end{array}$ & \multirow{4}{*}{ LW } & 0 & 3.8 & 5.4 & 7.5 & 8.3 \\
\hline M10LW & & 10 & 4.0 & 6.0 & 9.2 & 10.7 \\
\hline M20LW & & 20 & 4.3 & 7.3 & 10.5 & 12.4 \\
\hline M30LW & & 30 & 4.4 & 7.2 & 11.5 & 13.5 \\
\hline
\end{tabular}

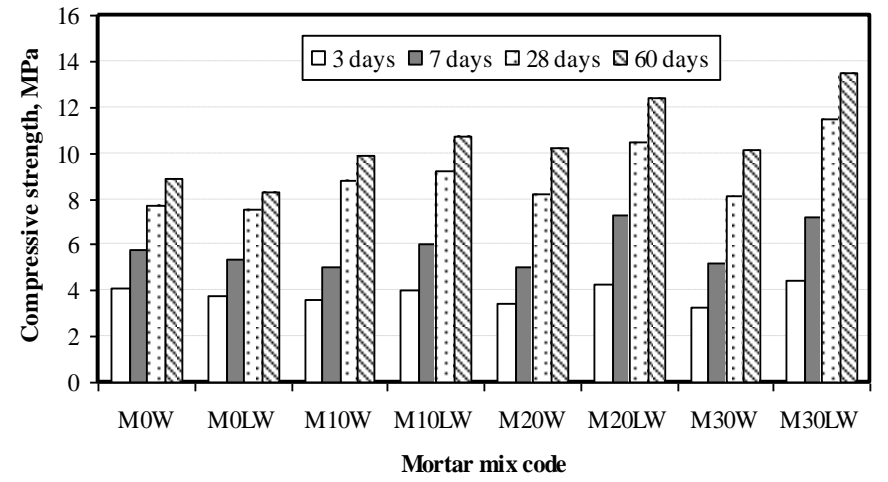

Fig. 5: Compressive strength for mortar mixes at different ages

\subsubsection{Strength development for concrete mixes}

Two groups of concrete mixes were investigated for compressive strength development. The first one was a series of Portland cement concrete mixes mixed with $\mathrm{W}$ and contained $0,10,20$ and $30 \% \mathrm{SF}$ and indexed as $\mathrm{C} 0 \mathrm{~W}, \mathrm{C} 10 \mathrm{~W}, \mathrm{C} 20 \mathrm{~W}$ and $\mathrm{C} 30 \mathrm{~W}$, respectively. Moreover, the second group was mixed with LW and contained 0, 10, 20 and $30 \%$ $\mathrm{SF}$ and indexed as C0LW, C10LW, C20LW and C30LW, respectively. The compressive strength results for both groups are presented in Table 5 and Fig. 6.

For first group, it can be noticed that the compressive strength increases with the increase of SF content up to a certain content beyond which the strength is decreased. Figure 6 shows that at $20 \%$ SF, higher strengths have been achieved at 28 and 60 days age. The maximum enhancement at 60 days age is $12 \%$ for $\mathrm{C} 20 \mathrm{~W}$ over the control mix C0W.

For second group for which LW is used, it can be noticed that the measured compressive strength values increase with the increase of SF content up to the maximum used SF content 30\%. Remarkable enhancements are recorded at both early ages and late ages as well. For mix C30LW the enhancements are $21 \%, 30 \%, 20 \%$ and $32.2 \%$ over the control mix C0W at 3, 7, 28 and 60 days age, respectively.

For mix without SF and mixed with LW (mix COLW) reduction of the measured compressive strength values are noticed at all ages compared to mix C0W and $10.7 \%$ decrease of the compressive strength is recorded at 60 days age. This reduction may be due to the retardation phenomena previously noticed with setting times. 
Table 5: Test results of concrete mixes compressive strength at different ages

\begin{tabular}{|c|c|c|c|c|c|c|}
\hline \multirow{2}{*}{$\begin{array}{l}\text { Mix } \\
\text { Code }\end{array}$} & \multirow{2}{*}{$\begin{array}{l}\text { Type of } \\
\text { mix } \\
\text { solution }\end{array}$} & \multirow{2}{*}{$\begin{array}{c}\mathrm{SF}, \\
\%\end{array}$} & \multicolumn{4}{|c|}{ Compressive strength, $\mathrm{MPa}$} \\
\hline & & & 3 & 7 & 28 & 60 \\
\hline $\begin{array}{c}\text { C0W } \\
\text { (control) }\end{array}$ & \multirow{4}{*}{ W } & 0 & 10.5 & 18.0 & 26.0 & 28.0 \\
\hline C10W & & 10 & 10.0 & 19.0 & 23.4 & 25.0 \\
\hline C20W & & 20 & 8.5 & 17.5 & 29.0 & 31.4 \\
\hline C30W & & 30 & 8.1 & 15.5 & 27.5 & 30.8 \\
\hline $\begin{array}{c}\text { C0LW } \\
\text { (control) }\end{array}$ & \multirow{4}{*}{ LW } & 0 & 9.0 & 15.2 & 23.4 & 25.0 \\
\hline C10LW & & 10 & 11.0 & 20.0 & 30.0 & 33.4 \\
\hline C20LW & & 20 & 12.0 & 22.0 & 29.5 & 35.0 \\
\hline C30LW & & 30 & 12.7 & 23.4 & 31.2 & 37.3 \\
\hline
\end{tabular}

\subsection{Consumptions of CH crystals}

To follow up the pozzolanic reaction of SF with and without LW, XRD analysis was conducted at different ages and the pattern are shown in Figs. 711. The consumptions of $\mathrm{CH}$ crystal contents could be demonstrated approximately by intensity changes of main diffraction peaks of $\mathrm{CH}$ crystals, such as B1 crystal face, as well as B2 and B3 crystal faces $(\mathrm{d}=0.490,0.310$ and $0.263 \mathrm{~nm}$, respectively [20], where $d$; lattice spacing in a crystalline sample as given by the well known Bragg's law). At the same ages, diffraction peak intensities of B2 and B3 crystal faces of $\mathrm{CH}$ for the investigated samples were almost close to those for control samples. In contrary, noticeable differences were recorded at the intensities of B1crystal face.

Considering the intensities of B1 it could be noticed that the intensity values for all mixes mixed with LW are higher compared to the corresponding mixes mixed with $\mathrm{W}$. The trend was noticed for mixes without SF as well as those containing $10 \%$, $20 \%$ and $30 \%$ SF at different ages as given in Figs. 7-11.
Due to the high content of $\mathrm{CH}$ crystals contained in mixes made up of LW this can help maximizing the replacement of cement by SF. Figure 11 shows the XRD patterns for all mixes containing $30 \%$ SF at different ages. Moreover, it could be realize that at early ages, the intensity of $\mathrm{CH}$ crystals are higher for mixes made up of LW compared to those mixed with $\mathrm{W}$, whereas, at 60 days age, the $\mathrm{CH}$ crystals are consumed in mix containing $30 \%$ SF and there was still an amount of $\mathrm{CH}$ crystals in mix $\mathrm{C} 30 \mathrm{LW}$ available for further pozzolanic reaction to take place to form more of Calcium Silicate Hydrate $\mathrm{CSH}$. That result supports the enhancement in compressive strength especially at later ages for mortar and concrete mixes at higher percentages of SF $30 \%$ compared to $20 \%$ for mixes made up of $\mathrm{W}$. Moreover, and science the $\mathrm{CSH}$ phase is nearly amorphous material, its structure cannot be studied by XRD [21]. The measured compressive strengths could be considered as a measure for the formation of CSH resulting from both of hydration process of cement as well as the pozzolanic reaction.

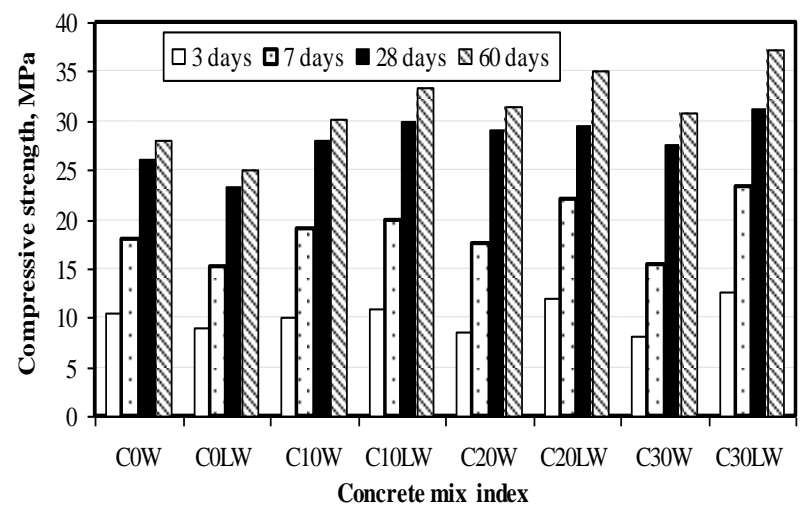

Fig. 6: Compressive strength for concrete mixes at different ages

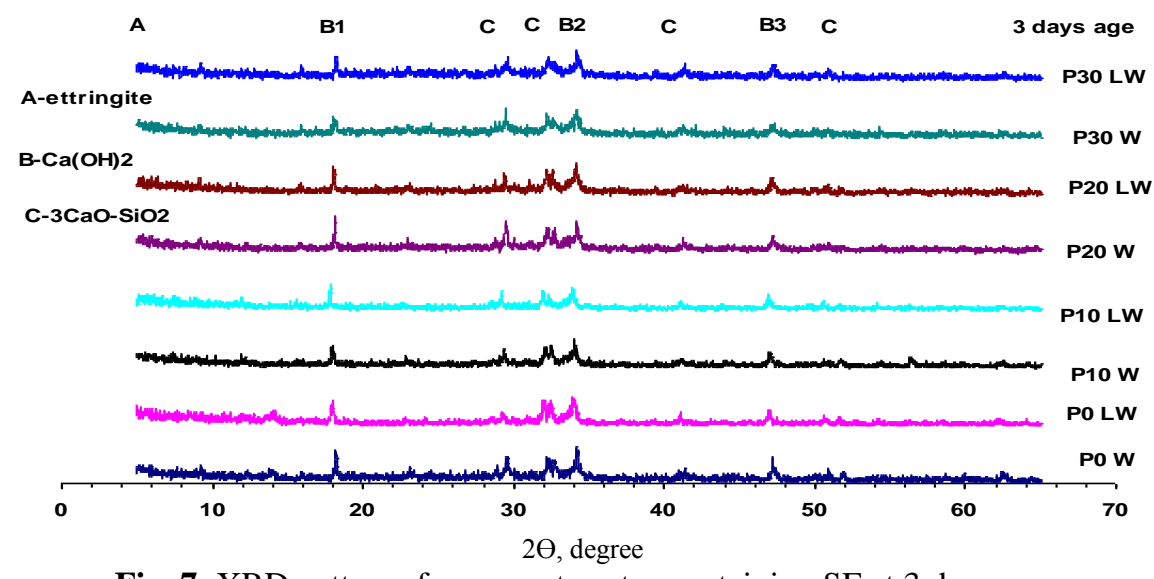

Fig. 7: XRD patterns for cement pastes containing SF at 3 days age 


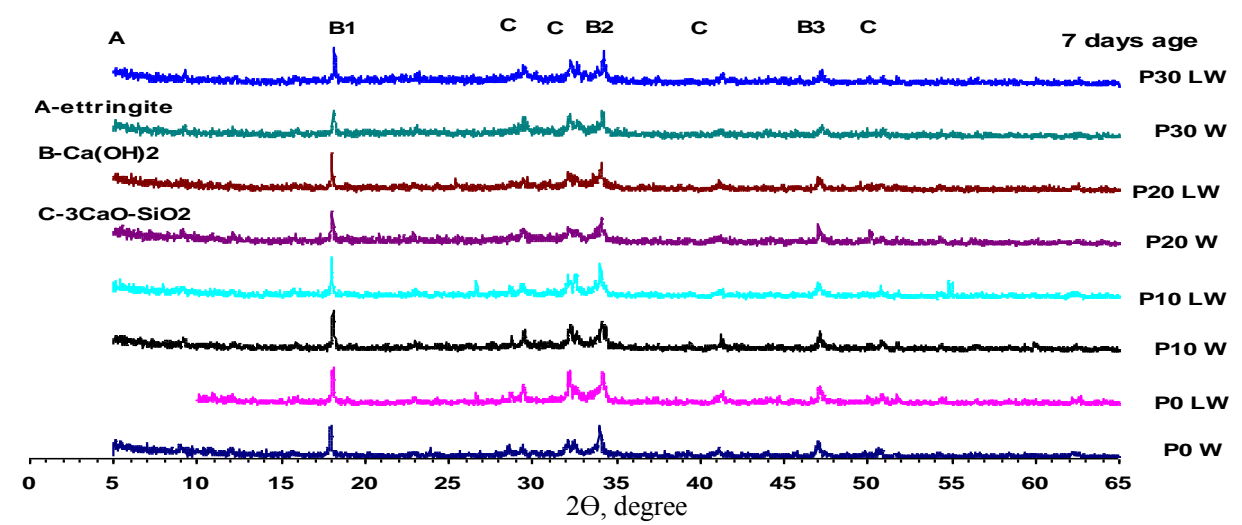

Fig. 8: XRD patterns for cement pastes containing SF at 7 days age

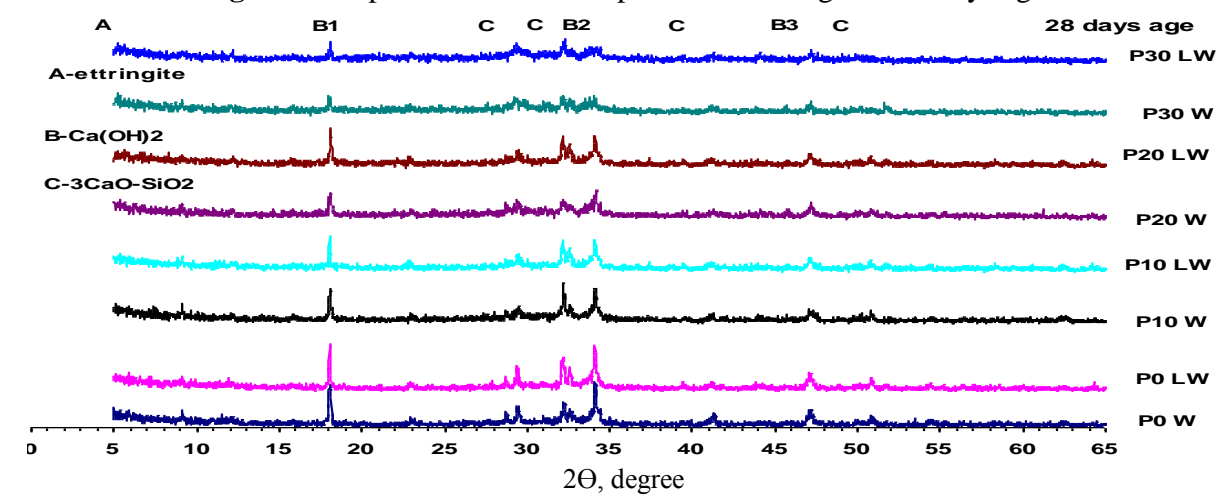

Fig. 9: XRD patterns for cement pastes containing SF at 28 days age

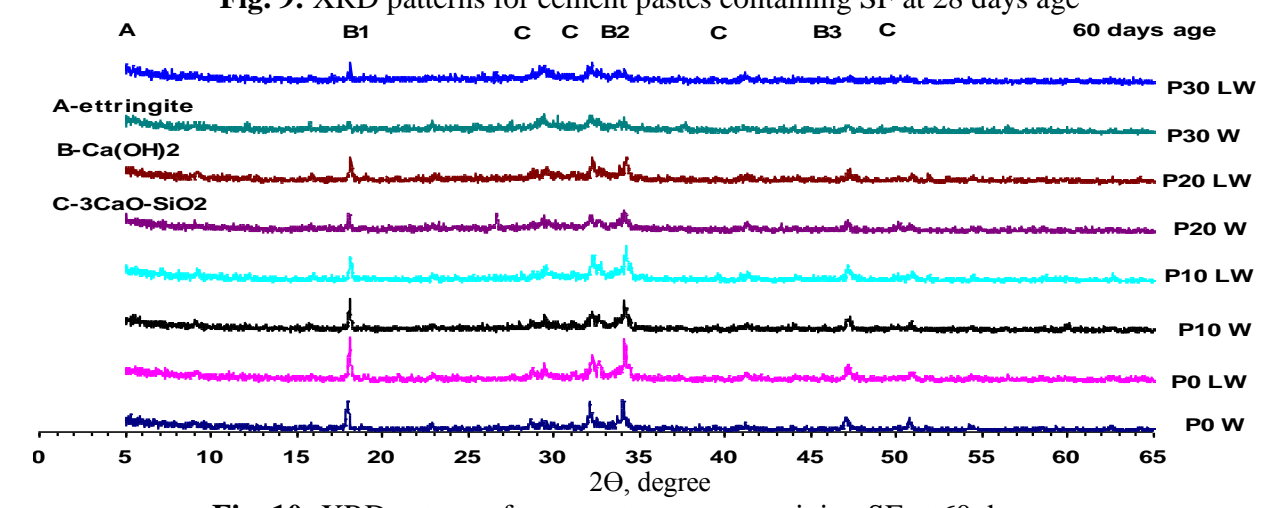

Fig. 10: XRD patterns for cement pastes containing SF at 60 days age
$\mathbf{A}$
B1 C C B2
C B3 C
60 days age

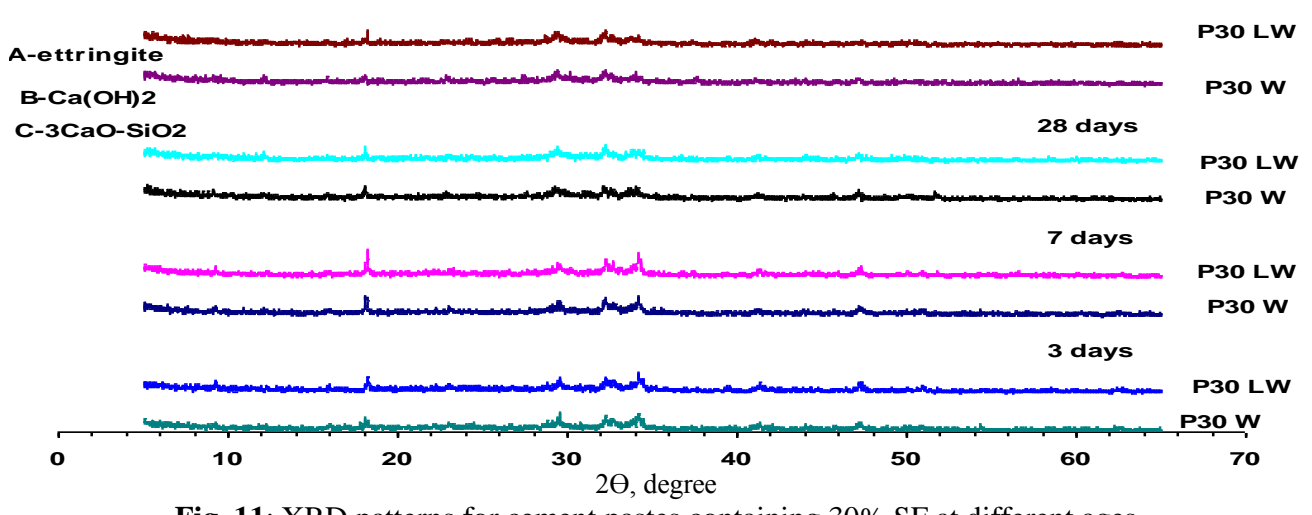

Fig. 11: XRD patterns for cement pastes containing $30 \% \mathrm{SF}$ at different ages 


\subsection{Corrosion resistance of modified concrete mixes}

Using LW as a concrete mixing solution parallel with SF was evaluated on corrosion characteristics. An accelerated corrosion test procedure was adopted as presented in Fig. 2. Periods to first crack as well as the mass loss measurements were the evaluated parameters. Figure $\mathbf{1 2}$ shows the interface between the extracted steel bars and concrete after exposure for mixes $\mathrm{COW}$ and C30LW, respectively. Whereas, the final appearance of the extracted steel bars at the end of the exposure test to chloride are presented in Fig. 13.

Periods to first crack are presented in Fig. 14. The periods to fist crack are 50, 90, 92 and 194 days for mixes C0W, C10W, C20W and C30W, respectively. Whereas, for mixes mixed with $\mathrm{LW}$ the corresponding elapsed period are 54, 120, 140 and 260 days for C0LW, C10LW, C20LW and C30LW, respectively. It could be noticed that using LW alone in mixing dose not significantly influences the elapsed time to first crack. Moreover, replacing part of Portland cement with SF extended the period required for first crack for mixes mixed with water which my be related to the relatively dense microstructure of mixes containing SF. Furthermore, better results of delaying the occurrence of the first crack was achieved when both of SF parallel with LW was used in concrete mixes. That retardation may be due to the denser structure, which is created when LW and SF are added to concrete mixes as well as the formed passive layer surrounding steel bars.

Losses of embedded steel bars as an indicator for corrosion resistance are presented in Fig. 15. Percentages of mass loss for mixes mixed with $\mathrm{W}$ are 29, 19, 12 and $17 \%$ for mixes C0W, C10W, C20W and C30W, respectively. Whereas, for mixes mixed with $\mathrm{LW}$ the corresponding loss percentages are 27, 15, 11 and $4 \%$ for mixes C0LW, C10LW, C20LW and C30LW, respectively. Remarkable enhancements in corrosion resistance are clear especially when LW parallel with SF are used, Figs. 12-15. With increasing $\mathrm{SF}$ in concrete mix and with the existence of LW the microstructure becomes denser and the permeability is decreased which consequently leads to better resistance to corrosion.

The positive results of using SF on retardation and making a resistance to corrosion could be agreed well with the results reached in reference [23].
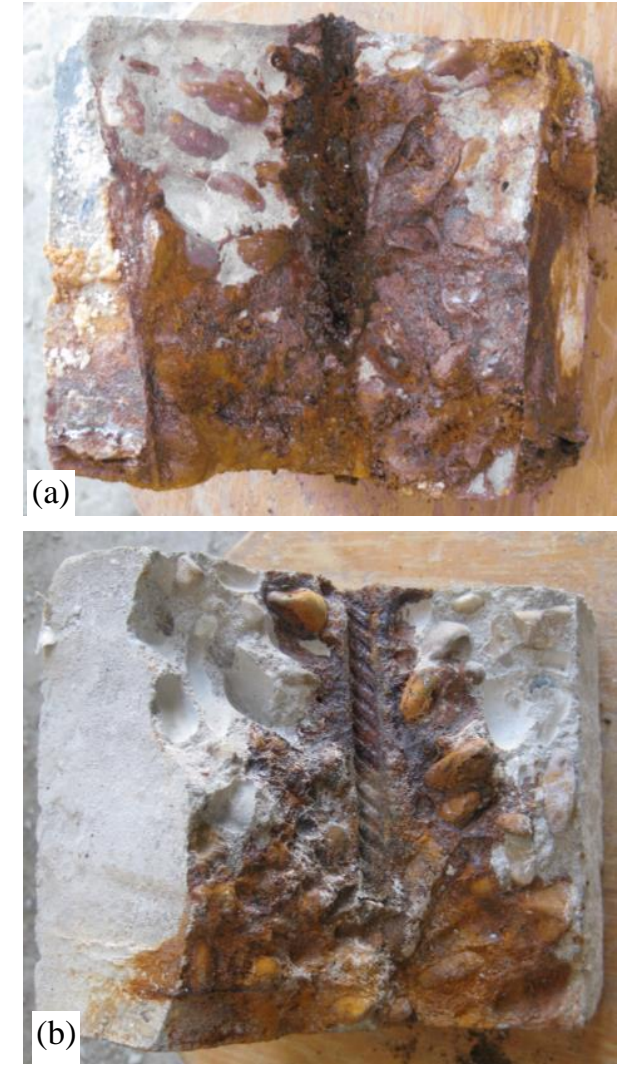

Fig. 12: Interface between the corroded steel bars and concrete (a; COW and b; C30LW)

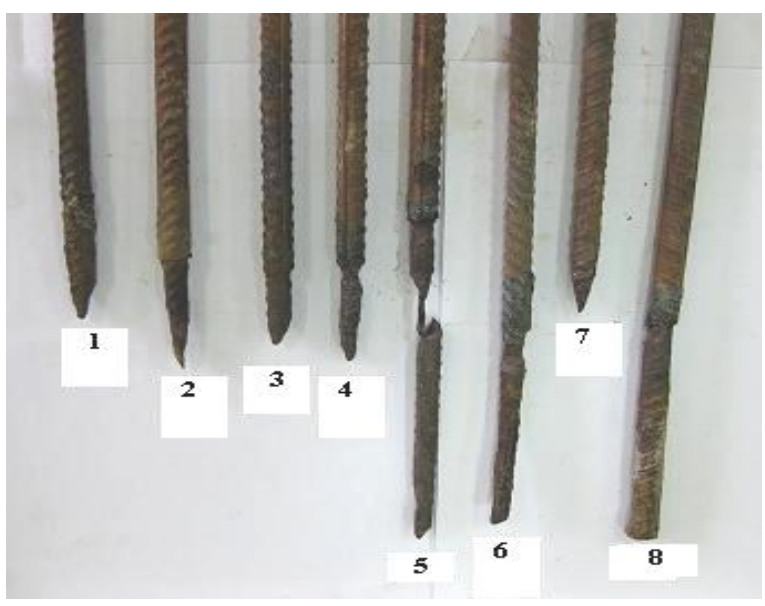

Fig. 13: Corroded steel bars due to chloride attach at the end of the test $(1 ; \mathrm{COW} .2$; COLW, $3 ; \mathrm{C} 10 \mathrm{~W}, 4$; C10LW, 5; C20W, 6; C20LW, 7; C30W, 8; C30LW) 


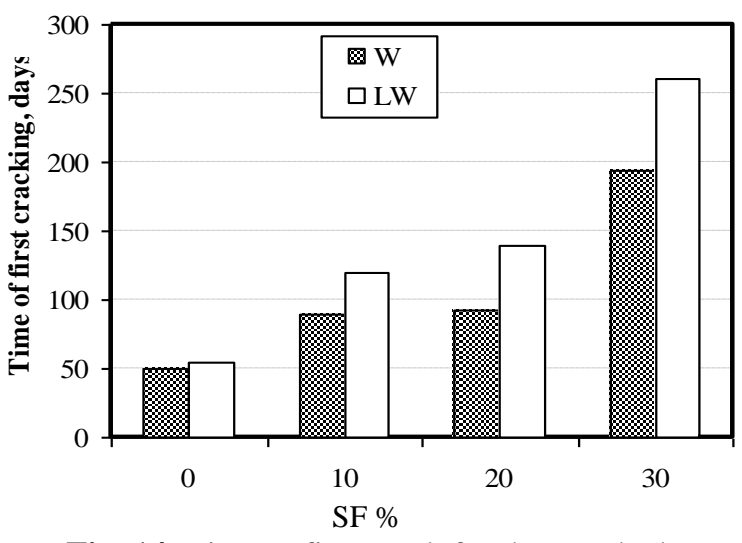

Fig. 14: Time to first crack for the attached concrete specimens

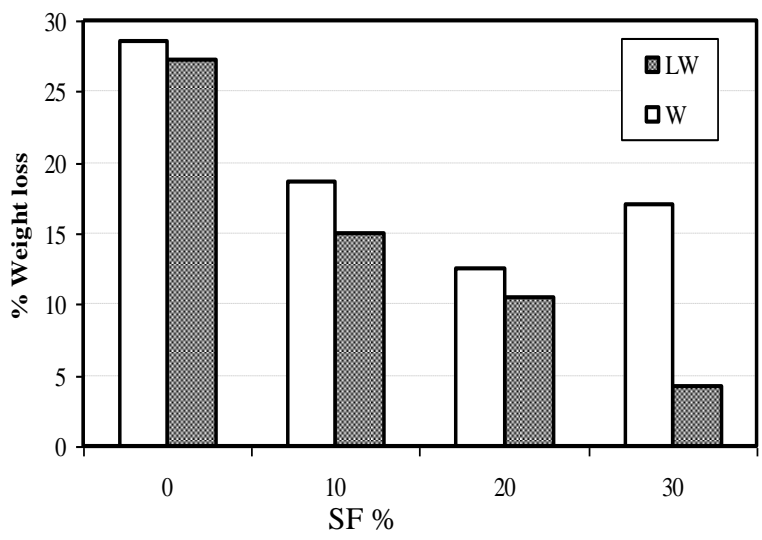

Fig. 15: Percentage of weight loss of the corroded steel bars due to the chloride attack

\section{CONCLUSIONS}

Combination use of SF and LW in mixing Portland cement based composites affects both of fresh and hardened properties as well as performance of concrete mixes. Based on the test results and discussion, the following conclusion could be drawn for the current study as follows:

1. Using of LW as a mixing solution delays both of initial and final setting times for Portland cement based materials as well as mixes containing SF. The maximum delay was recorded for cement paste as $90 \mathrm{~min}$ and $115 \mathrm{~min}$ for initial and final setting times for mixes P20LW and P40LW over the control mix P0W, respectively.

2. The combined use of SF and LW in Portland cement concrete mixes delayed both of initial and final setting times. The maximum delay in initial setting time was noticed for mix C30LW as $83 \%$ over the control mix C0W. Moreover, $86 \%$ delay of final setting times was recorded for mix C30LW over the control mix COW.
3. Using LW as a mixing solution delays the strength development at both early and late ages. Whereas, combination use of LW and silica fume enhances both of early and late strengths for cement mortar and concrete mixes.

4. $12 \%$ maximum increase of compressive strength for mix C20W was achieved at 60 days age. Whereas, $32 \%$ increase of the compressive strength was reached for mix C30LW at 60 days age over the control mix which means $30 \% \mathrm{SF}$ replacement of cement weight could be achieved and give better enhancement in compressive strength when replacing tap water by LW in mixing.

5. Based on XRD results, Portland cement based mixes mixed with LW can consume large amount of SF compared with those mixed with water. For best compressive strength, mixes made up of water can consume10-20\% SF as a replacement of cement whereas, LW mixes can consume $30 \%$ or more as a replacement of cement by mass.

6. From durability point of view, when LW is used in concrete mixing which contains SF, significant delays in first crack as well as a decrease in the mass loss of steel bars are observed. For such mixes, an extension of the service life time periods are expected.

\section{REFERENCES}

[1] Fr1'as M., Sa'nchez de Rojas M.I., "Microstructural Alterations in Fly Ash Mortar: Study on Phenomena Affecting Particle and Pore Size", Cement and Concrete Research, Vol 27, No 2, 1997, pp. 50-57.

[2] Cabrera J.G., Nwaubani S.O., "The Microstructure and Chloride Ion Diffusion Characteristic of Cements Containing Metakaolin and Fly Ash", in: V.M. Malhotra (Ed.), $6^{\text {th }}$ International Conference on Fly Ash, Silica Fume, Slag and Natural Pozzolans in Concrete, CANMET/ ACI SP-178, Bangkok, Vol. 1, 1998, pp. 385-400.

[3] Thomasa M.D.A., Shehataa M.H., Shashiprakasha S.G., Hopkinsb D.S., Cailb K., "Use of Ternary Cementitious Systems Containing Silica Fume and Fly Ash in Concrete", Cement and Concrete Research, Vol 29, 1999, pp. 1207-1214. [4] Chan R.W.M., Ho P.N.L., Chan E.P.W., "Concrete Admixture for Waterproofing Construction, Structural Engineering Branch", Architectural Services Department, Technical Report, Structural Materials Group, 1999, pp. 41.

[5] ACI Committee 234, "Guide for the Use of Silica Fume in Concrete", ACI 234R-06, 2008. 
[6] Marriaga J.L., López Yépez L.G., "Effect of Silica Fume Addition on the Chloride-Related Transport Properties of High-Performance Concrete", Dyna, year 79, Medellin, February, 2012. ISSN 0012-7353No. 171, pp. 105-110.

[7] Rojas M.F., Cabrera J., "The Effect of Temperature on the Hydration Rate and Stability of the Hydration Phases of Metakaolin-Lime-Water Systems", Cement and Concrete Research 32, 2002, pp. 133-138.

[8] Papadakis V.G., 'Effect of Fly Ash on Portland Cement Systems Part II. High-Calcium Fly Ash, Cement and Concrete Research 30, 2000, pp. 16471654.

[9] Wild S., Khatib J.M., Jones A., "Relative Strength, Pozzolanic Activity and Cement Hydration in Superplasticised Metakaolin Concrete', Cement and Concrete Research, Vol. 26, No. 10, 1996, pp. 1537-1544.

[10] Frı'as M., Sa'nchez de Rojas M.I., Cabrera J., "The Effect that the Pozzolanic Reaction of Metakaolin Has on the Heat Evolution in MKCement Mortar", Cement Concrete Research, Vol 30, 2000, pp. 209-216.

[11] Boynton R., "Chemistry and Technology of Lime and Limestone", Interscience Pub., New York, 1966.

[12] Oca J.J.D., Hernandez J.F.M., Rodríguez L., López R.G., "Effect of Lime- Zeolite Binder on Compression Strength and Durability Properties of Concrete", Revista Ingeniería de Construcción, Vol. 24, No 2, 2009, www.ing.puc.cl/ric, pp. 181-194.

[13] Barbhuiya S.A., Gbagbo J.K., Russell M.I., Basheer P.A.M., "Properties of Fly Ash Concrete Modified with Hydrated Lime and Silica Fume", Construction and Building Materials, 23, 2009, pp. 3233-3239.

[14] Mehta P.K., "Role of Pozzolanic and Cementitious Material in Sustainable Development of the Concrete Industry", Proceedings of the $6^{\text {th }}$ International Conference on the Use of Fly Ash, Silica Fume, Slag, and Natural Pozzolans in Concrete", ACI SP-178, 1, Bangkok, 1998.
[15] Thompson N.G., Lankard D.R., "Improved Concretes for Corrosion Resistance", Federal Highway Administration, US Department of Transportation, Georgtown Pike, McLean VA, Report No. FHWARD- 96-207, 1997.

[16] Mira P., Papadakis V.G., Tsimas S., "Effect of Lime Putty Addition on Structural and Durability Properties of Concrete", Cement and Concrete Research, Vol. 32, 2002, pp. 683-689.

[17] Gleize P.J.P., Müller A., Roman H.R., "Microstructural Investigation of a Silica FumeCement-Lime Mortar", Cement and Concrete Composites, Vol 25, No 2, 2003, pp. 171-175.

[18] ASTM C 187 - 98, American Society for Testing and Materials, "Standard Test Method for Normal Consistency of Hydraulic Cement1", West Conshohocken, United States, pp. 2.

[19] Alshamsi A.M., Sabouni A.R., Bushlaibi A.H. "Influence of Set Retarding Superplasticizers and Microsilica on Setting Time of Pastes at Various Temperatures", Cement and Concrete Research, Vol 23, No 3, 1993, pp. 592-598.

[20] Qing Y., Zenan Z., Deyu K., Rongshen C. , "Influence of Nano-SiO2 Addition on Properties of Hardened Cement Paste as Compared with Silica Fume", Construction and Building Materials, Vol 21, No 3, 2007, pp. 539-545.

[21] Peter C. Hewlett, Lea's, "Chemistry of Cement and Concrete", Fourth Edition, Elsevier Butterworth-Heinemann, Linacre House, Jordan Hill, Oxford OX28DP, 2005.

[22] Rao G.A., "Investigations on the Performance of Silica Fume-Incorporated Cement Pastes and Mortars", Cement and Concrete Research, Vol 33, No 11, 2003, pp. 1765-1770.

[23] Dotto J.M.R., De Abreu A.G., Dal Molin D.C.C., Muller I.L., "Influence of Silica Fume Addition on Concretes Physical Properties and on Corrosion Behaviour of Reinforcement Bars", Cement and Concrete Composites, 26, 2004, pp. 31-39. 